\title{
The history of mapping the apple genome
}

\author{
Sylwia Keller-Przybytkowicz, Matgorzata U. Korbin*
}

\author{
Department of Fruit Plant Breeding \\ Laboratory of Unconventional Breeding Methods \\ The Research Institute of Horticulture \\ Konstytucji 3 Maja 1/3, 96-100 Skierniewice
}

\begin{abstract}
This review summarises the research projects that have been conducted with the goal of mapping the apple $($ Malus $\times$ domestica) genome. The generation of apple linkage and physical maps, which was started at the end of the $20^{\text {th }}$ century by many scientific teams, has resulted in rich data useful for further fundamental and applied studies. The mapping efforts mainly contained the choice of mapping populations as well as the choice of types and number of markers. Over the years, scientists have achieved major successes and faced major obstacles. Many economically important traits have been mapped in the apple genome, which has a total length of 2000 $\mathrm{cM}$. The recently published integrated genetic and physical maps summarise the data and will be helpful to modern breeding programs, with a special focus on resistance to various diseases, as well as on fruit quality and other desired apple traits.
\end{abstract}

Key words: linkage map, Malus $\times$ domestica, physical map

\section{INTRODUCTION}

Genome mapping establishes the "road map" of the genome (Kole and Abbott 2008). The mapping of chromosomes helps to locate important genes and identify the molecular environment of coding and non-coding DNA sequences. Based on the manner of their generation, two types of maps are featured: the genetic map and the physical map. The first one shows the order of genes and the distance between them (expressed as the percentage of recombination) and is measured in centiMorgans $(\mathrm{cM})$. The physical maps present the actual physical position of genes with distances measured in base pairs (bp). Both the genetic and physical maps can be applied for crop improvement. For instance, markers linked to genes and/or QTL can be used for the introgression of favourable alleles of genes, for selection in breeding programs, and for screening germplasm for targeted traits (Kole and Abbott 2008). Thus, maps are considered a valuable tool for contemporary agriculture, particularly for present-day breeding.

The domesticated apple (Malus $\times$ domestica Borkh., family Rosaceae, subfamily Maloideae) (Hummer and Janick 2008) is cultivated all across the temperate world and the annual world production of this fruit exceeds 73 million metric tons (FAOSTAT 2011). The apple has long been considered a result of allopolyploidization between species related to the subfamilies Spiraeoideae $(n=9)$ and Amygdaleoideae $(n=8)$, with possible autopolyploidization events (Evans and Campbell 2002). More recently, genome-wide duplications have been suggested as the cause of the transition

\footnotetext{
*Corresponding author.

Tel.: +48 4683452 69; fax: +48 4683452 69;

e-mail: malgorzata.korbin@inhort.pl (M. Korbin).
} 
from nine ancestral chromosomes to 17 (Velasco et al. 2010). The size of the Malus genome is relatively small (742.3 Mbp/1C) and comparable in length to that of the tomato (Shulaev et al. 2008).

Over the years, many apple maps have been generated. The Genome Database of Rosaceae (www.rosaceae.org) and databases derived from European Malus projects such as HiDRAS (www. hidras.unimi.it) display several reference maps of the apple genome, allowing users to focus on regions of interest, or align maps for comparative purposes (Jung et al. 2008).

In this review the authors would like to present the history of apple genome mapping by emphasising the successes and the obstacles of these research efforts.

\section{Mapping populations}

The choice of mapping population is critical for successful map construction. Self-incompatibility and the long juvenile period of $M . \times$ domestica (3-10 years) limit the generation of segregating populations such as $\mathrm{F}_{2}, \mathrm{~F}_{2: 3}, \mathrm{BC}$ or RIL, which are commonly used for the mapping of other plant species. Therefore, the apple maps were built on $F_{1}$ obtained from inter/intraspecific cross pollination (CP) of various cultivars characterised by high heterozygosity (Maliepaard et al. 1998).

The first segregating population resulted from the cross 'Rome Beauty' $\times$ crabapple 'White Angel' contained only 56 genotypes (Hemmat et al. 1994). Later on, the number of progeny extended from 100 to 200 genotypes ('Wijcik McIntosh' $\times$ NY 7544167, 'Wijcik McIntosh' $\times$ NY 75441-58; 'Ralls Janet' $\times$ Mitsubakaido, 'Delicious' $\times$ Mitsubakaido) (Conner et al. 1997, Igarashi et al. 2008), and from 250 to 300 progeny ('Prima' $\times$ 'Fiesta', 'Fiesta' $\times$ 'Discovery', 'Telamon' $\times$ 'Braeburn', 'Florina' $\times$ 'Nova Easygro') (Maliepaard et al. 1998, Liebhard et al. 2002, 2003a, Kenis and Keulemans 2005, Le Roux et al. 2010). In the last decade, numerous subsets of these previously described populations were re-used in order to increase the saturation level of individual maps (Calenge et al. 2004, 2005, Silfverberg-Dilworth et al. 2006). On the other hand, 60 progeny were applied at the beginning of the study on the 'Retina' $\times$ 'Topaz' bin-map (Keller-Przybyłkowicz 2011) and further analysis, including searches for specific QTLs, has been continued on new sub-populations derived from the same cross (unpublished data).

Using CarthaGene software, marker data generated earlier for 676 progeny of the crosses
'Discovery' $\times$ TN10-8, 'Fiesta' $\times$ 'Discovery', 'Discovery' $\times$ 'Prima' and 'Durello di Forli' $\times$ 'Fiesta' were applied for the construction of an integrated map of the apple genome (N'Diaye et al. 2008). Recently, Khan et al. (2012) built a global "virtual" consensus map using the GoldenGate genotyping platform (HTS) and data that had been obtained from several mapping populations, containing over 500 individuals in total.

\section{Molecular markers and linkage map construction}

The first skeletons of apple maps were built based on RAPD (Random Amplified Polymorphic DNA), RFLP (Restriction Fragment Length Polymorphism) and AFLP (Amplified Fragment Length Polymorphism) markers (Hemmat et al. 1994, Conner et al. 1997, Maliepaard et al. 1998, Kenis and Keulemans 2005). However, these markers have many disadvantages such as laborious genotyping (RFLP), dominant inheritance (AFLP, RAPD), low reliability (RAPD), and low level of polymorphism (RFLP, RAPD). The usefulness of some of the RAPD and RFLP markers for apple mapping increased after their conversion to SCAR markers (Sequence Characterized Amplified Regions) (Tartarini et al. 1999, Bus et al. 2005, Boudichevskaia et al. 2006).

In parallel, apple-specific microsatellites (SSR, Simple Sequence Repeat), which are highly polymorphic, transferable, easy to amplify and very reliable (Hokanson et al. 1998), became the marker of choice in the generation and saturation of apple maps (Gianfranceschi et al. 1998, Liebhard et al. 2002, Silfverberg-Dilworth et al. 2006, Keller-Przybyłkowicz 2011). Lately, SNPs (Single Nucleotide Polymorphism), have become very useful in apple mapping due to their high abundance and high throughput genotyping as well as their transferability not only between apple cultivars but even between Malus and Pyrus genomes (Antanaviciute et al. 2012). Moreover, the development of EST and SNP arrays provides high throughput genotyping for further linkage map construction and will greatly facilitate future QTL and association analysis (Antanaviciute et al. 2012).

In recent years, cDNA microarrays have become the source of new types of markers (Soglio et al. 2009). As a continuation of whole-genome profiling, diversity array technology (DArT) has also been applied in the mapping of the apple genome (Schouten et al. 2012).

Seventeen linkage groups (LGs) for the maternal 'Rome Beauty' and 24 LGs for the paternal 'White 
Angel' were described for the first apple map by Hemmat at al. (1994). Other early maps, based on the cross between 'Wijcik McIntosh' and NY 75441-67 / NY 75441-58, characterised 19 linkage groups for 'Wijcik McIntosh' (1206 cM in length), 16 linkage groups for NY 75441-67 (692 cM) and 18 linkage groups for NY 75441-58 (898 cM) (Conner et al. 1997).

The next genetic maps described 17 linkage groups, with total lengths of $843 \mathrm{cM}$ and $984 \mathrm{cM}$ for 'Prima' and 'Fiesta', respectively (Maliepaard et al. 1998), $1082 \mathrm{cM}$ and $1031 \mathrm{cM}$ for 'Ralls Janet' and 'Delicious' (Igarashi et al. 2008), $1039 \mathrm{cM}$ and $1245 \mathrm{cM}$ for 'Telamon' and 'Braeburn' (Kenis and Keulemans 2005), $1143 \mathrm{cM}$ and $1454 \mathrm{cM}$ for 'Fiesta' and 'Discovery' (Liebhard et al. 2003a) to $1991 \mathrm{cM}$ for the integrated M. × domestica map (Khan et al. 2012). The differences between the various maps were related to the type and number of the DNA markers. For instance, genotyping the progeny of the cross 'Rome Beauty' $\times$ 'White Angel' was carried out by 409 markers (Hemmat at al. 1994) whereas the linkage mapping of 'Fiesta' $\times$ 'Discovery' was carried out by 840 markers (Liebhard et al. 2002, 2003a), by 938 markers (Silfverberg-Dilworth et al. 2006) and by 1046 markers (N'Diaye et al. 2008). Almost 800 newly developed DArT markers increased the genome saturation from $55 \%$ to $76 \%$ for 'Prima' and from $60 \%$ to $74 \%$ for 'Fiesta' (Schouten et al. 2012). The newest integrated map based on 2875 SSRs and SNPs resulted in intervals between markers even smaller than $1 \mathrm{cM}$ (Khan et al. 2012).

\section{Gene loci and QTL regions on the M. $\times$ domestica maps}

The majority of major genes, gene markers and quantitative trait loci (QTL) located on the genetic maps are linked with plant resistance to economically important apple diseases.

Several SCAR markers related to the Rvi6 locus (formerly $V f$ ), primarily originating from M. floribunda Sieb. 821, which is monogenically resistant to apple scab caused by Venturia inaequalis (race 6), were identified on LG1 (Huaracha et al. 2004). The Rvil gene (formerly $V g$ ), originally described in 'Golden Delicious', which is resistant to race 1 of $V$. inaequalis, was localised on LG12 of 'Prima' (Durel et al. 2000). Further work on $M$. $\times$ domestica resistance to $V$. inaequalis, exploited by Bus et al. (2005) and Boudichevskaia et al. (2006), allowed the identification of two different $R$ genes: Rvi2 (Vh2) and Rvi4 ( $V r 1 / V h 4)$ carrying $V r$ regions on LG2 of Russian Seedling (Malus pumila R12740-7A). The apple scab resistance gene Rvi5 $(\mathrm{Vm})$, originally derived from $M$. micromalus, was located on linkage group 17 of 'Murray' (Cheng et al. 1998, Patocchi et al. 2005). The analysis of various mapping populations allowed the identification of further $R$ genes: Rvilo and Rvil7 (formerly $\mathrm{Va}$, scab resistance derived from 'Antonovka') on LG1 (Hemmat et al. 2003, Dunemann and Egerer 2010), Rvill ( $V b j$, apple scab resistance derived from Malus baccata jackii) on LG2 (Gygax et al. 2004) and Rvil2 ( $\mathrm{Vb}$, scab resistance from Hansen's baccata \#2) on LG12 (Hemmat et al. 2003, Erdin et al. 2006). Likewise, the Rvil3 gene ( $V d$, scab resistance from 'Durello di Forli') was located on LG10 (Tartarini et al. 2004, Soriano et al. 2009). In addition to $R$ genes, several QTL impacting scab resistance and a number of RGA (resistance gene analogues) have been identified from different apple cultivars (Liebhard et al. 2003b, Durel et al. 2003, Calenge et al. 2004, Gessler et al. 2006, Soufflet-Freslon et al. 2008).

The regions linked to polygenic apple resistance to fire-blight (caused by Erwinia amylovora) were detected on linkage group 3, 7 and 12 of 'Prima', 'Fiesta', 'Idared', M. robusta 5, 'Discovery', TN10-8, 'Evereste' and M. floribunda 821 (Calenge et al. 2005, Peil et al. 2007, Khan et al. 2006, 2007, Durel et al. 2009). Moreover, additive interactions of several additional resistance regions in the same genotype were identified (Calenge et al. 2005).

Several genes of resistance to powdery mildew (caused by Podosphaera leucotricha) were mapped on different apple chromosomes such as LG12 (Pl-1, resistance derived from Malus robusta) (Dunemann et al. 2007), LG11 (Pl-2, derived from Malus zumi and $\mathrm{Pl}$-mis from Mildew Immune Selection) (Alston et al. 2000, Gardiner et al. 2003), LG8 ( $\mathrm{Pl}-\mathrm{w}$, derived from crabapple 'White Angel') (Evans et al. 2003), and LG12 ( $P l-d$, derived from 'D12') (James et al. 2004). The analysis of 'Discovery' $\times$ TN108 progeny allowed for the mapping of additional QTL regions connected with powdery mildew resistance on LGs 2, 8, 13, 14, and 17 (Calenge and Durel 2006). Genes conferring resistance toward the woolly apple aphid (Eriosoma lanigerum) such as $\operatorname{Erl}$ (originated from 'Northern Spy') and $\operatorname{Er} 3$ (from Malus sieboldii) were mapped on LG8, whereas Er2 gene (from M. robusta) was located on LG17 (Bus et al. 2007). The gene $D p-f l$ conferring resistance toward the rosy apple aphid (Dysaphis plantaginea Passerini) was mapped on LG8 (Dapena et al. 2009). Moreover, leaf curling aphid (Dysaphis 
devecta $\mathrm{Wlk}$ ) resistance gene ( $S d 1)$, described firstly by Roche et al. (1997), was revealed on LG7 of the cultivar 'Florina' (Cevik and King 2002).

Studies on genes and regions controlling many other plant traits have also been conducted from the beginning of apple mapping. Putative QTL regions controlling blooming behaviour were expected on LG7, 8, 10, 15, 17, sugar content on LG3, 6, 8, 9, 14, acidity on LG8 and LG16, and the juvenile period on LG3 and LG15 of the first 'Fiesta' $\times$ 'Discovery' - based map (Liebhard et al. 2003c). Maliepaard et al. (1998) localised putative QTL of fruit acidity (LG16) and juvenile period (LG3 and LG15) of 'Prima' $\times$ Fiesta'. The position of these QTL was confirmed in more recent investigations carried out on 'Telamon' $\times$ 'Braeburn' progeny (Kenis and Keulemans 2004, 2007, 2008 ). In a study on the same progeny, QTLs of fruit harvest (LG3, LG9, LG16), yield (LG5, LG15, LG16), fruit weight (LG2, LG6, LG10), fruit browning (LG17) (Kenis et al. 2008), and the content of fruit vitamin C (LG6, 10, 11 and 17) (Davey et al. 2006) were identified. However, despite such a broad spectrum of research on the location of QTL regions on the apple map, so far only some aspects of this knowledge have found applications in the practical breeding of this species.

Recently, functionally characterised markers that diversify phenotypical variations in regard to sequence motifs have become very reliable for genetic map saturation (Andersen and Lübberstedt 2003). For instance, the functional markers adequate to sequences of genes associated with the regulation of ethylene synthesis and fruit firmness such as $A C O$ (1-aminocyclopropane-1-carboxylate oxydase) and ACS (1-aminocyclopropane-1carboxylate synthase) were mapped on LG10 and LG15, respectively (Harada et al. 2000, Costa et al. 2005, Soglio et al. 2009). Han et al. (2007, 2008) and Fernandez-Fernandez et al. (2008) described additional functional markers: sequences coding $\beta$-cyanoalanin synthase and ubiquitin $\mathrm{F}_{1}$ related protein $M d F B C P 1$, neighbouring the $A C O$ alleles on LG10, and the Ethylene Receptor gene (ETR1) regulating fruit ripening, near the $A C S$ alleles (Fernandez-Fernandez et al. 2008). The study of EST homologues to expansine (Exp7) and polygalacturonase (MdPG1) genes, both controlling fruit softness, allowed the localisation of these sequences on the first linkage group of 'Prima' (Costa et al. 2008) and LG10 of 'Mondial Gala' (Costa et al. 2010), respectively. The markers related to sequences of $G f c$ and $R n i$ genes associated with fruit flesh colour and the MdMYB10 gene (anthocyanin biosynthesis regulator) were mapped on chromosome IX in the progeny of the crosses 'Sciros' $\times$ 91.136 B6-77, 'Geneva' $\times$ 'Beaeburn' and 'Fiesta' $\times$ 'Totem' (Chagne et al. 2007, FernandezFernandez et al. 2008).

The analysis of selected segments of 'Retina' and 'Topaz' genome allowed the mapping of four genes responsible for plant defence: defensin peroxidase (DefPerox) on LG14 of 'Retina', glutathione S-transferase class-phi (GluStra) on LG3 of 'Retina' and the metallothionein-like protein type 3 and 2 (MALDO3, MALDO2) on LG3 and LG12 of 'Topaz', respectively. Other markers derived from ESTs of genes responsible for sugar metabolisms, including GFglyTra - UDP glucose: flavonoid 3-o-glucosyl transferase, PSTP - putative sugar transporter protein, and $P S T$ - putative sugar transporter, were mapped on LG2 of 'Retina' and 'Topaz', on LG12 of 'Topaz' and on LG14 of 'Retina'. Ascorbate peroxidase (homolog $A P X$ - PGiso1B) locus was identified on LG12 of the 'Topaz' genome (Keller-Przybyłkowicz 2011).

\section{Generation of a genetic apple map - obstacles and errors}

The major critical points in apple map generation include: the choice of appropriate parental forms and progeny set for efficient mapping, the selection of flanking markers, as well as the proper screening methodology for QTL analysis (Liebhard and Gessler 2002). In general, high heterozygosity of the parents results in a segregation of the markers and allows for the determination of the distance between them and the genes of interest, by measuring the recombination frequency using the formula: $1 \%$ of recombination equals $1 \mathrm{cM}$ (Lander and Botstein 1989). The statistical significance of the results is estimated by a LOD Score (Logarithm of the ODD) and ML (maximum likelihood) (Van Ooijen 1999, 2001). Various QTL mapping software programs are available, including fixed model (Xu and Atchley 1995), individual marker locus model (Knapp et al. 1990), segmental mapping (Perez-Enciso et al. 2000) and functional mapping (Ma et al. 2002). The various methodologies consider factors such as segregation type, input files, mapping function and thresholds setups, which affect the quality and the reliability of the map. It is noteworthy that problems arising from the incorrect scoring of markers, an improper assembly of the mapping results (after the calculation of the "goodness of fit" for each marker), as well as unsuitable software setups 
have been reported since the beginning of genetic mapping (Lander and Botstein 1989, Liebhard and Gessler 2000, Van Ooijen 2001).

\section{Physical maps of the apple genome}

The first $M . \times$ domestica physical maps were based on a partial sequencing of regions controlling the resistance to apple scab, using BAC-libraries constructed for 'Florina'(Vinatzer et al. 1998) and for M. floribunda 821 (Patocchi et al. 1999a,b, Xu et al. 2001). A more developed physical map was obtained by screening 3,744 BAC contigs (Han et al. 2008, 2009). The predicted genes covered a broad range of functional categories, such as cellular components, signal transduction, metabolism and stress response (32,250 genes). Han et al. (2008) determined the total coding region of the apple genome in the physical map of 'GoldRush' to be 64.5 Mbp.

Recently, physical mapping strongly supported by new computational tools and evolved by advanced high-throughput sequencing technologies has resulted in the recognition of a sequence of the entire apple genome (Velasco et al. 2010). After assembling and anchoring, the 'Golden Delicious' genome was found to contain 17 chromosomes (with $98 \%$ coverage of the apple genome), in a total length of $742.3 \mathrm{Mbp}$. This physical map contained 57,386 putative genes (including 11,444 genes specific for apple), 31,678 transposable elements and numerous repeated sequences. Simultaneously, a physical map of 'Royal Gala' with 19,732 sequences, representing about $60 \%$ of the total genome, was generated by Sanzol (2010). Both groups showed high levels of genome duplications followed by translocation and deletion events (Sanzol 2010, Velasco et al. 2010). Velasco et al. (2010) suggested that each doublet in the original set of eight chromosomes originated from one ancestor via inter-chromosomal rearrangements between chromosomes III and XI, V and X, IX and XVII and XII and XVI. Based on the physical maps, Han et al. (2011) concluded that the homology between pairs of linkage groups I and VII, II and XV, III and XI, IV and XII, V and X, VI and XIV, VIII and XV and IX and XVII demonstrates a large number of duplications in the apple genome.

\section{SUMMARY}

The generation of both the genetic and physical maps of apple widen the knowledge regarding the structure and origin of the $M . \times$ domestica genome. Further generation maps have become important for marker-assisted crop improvement, for the introgression of single genes and pyramiding breeding in the case of complex and polygenic traits. In addition, these maps are useful for the dissection of gene interactions and the identification of favourable alleles in segregating populations. However, before the application of this knowledge (and especially to new apple cultivars), one must validate the data.

\section{REFERENCES}

Alston F.H., Phillips K.L., Evans K.M., 2000. A Malus gene list. Acta Hort. 538: 561-570.

Andersen J.R., LÜBberstedt T., 2003. Functional markers in plants. Trends Plant Sci. 8(11): 554-560.

Antanaviciute L., Fernandez-Fernandes F., Jansen J., Banchi E., Evans K.M., Viola R., et al., 2012. Development of a dense SNP-based linkage map of apple rootstock progeny using the Malus infinium whole genome genotyping array. Genomics 13: 203.

Boudichevskaia A., Flachowsky H., Peil A., Fischer C., DunEmann F., 2006. Development of a multiallelic SCAR marker for the scab resistance gene $\mathrm{Vr} 1 / \mathrm{Vh} 4 /$ $V x$ from R12740-7A apple and its utility for molecular breeding. Tree Genet. Genomes 2: 186-195.

Bus V.G.M., RikKerink E.H.A., Van De Weg W.E., Rusholme R.L., Gardiner S.E., Bassett H.C.M., et al., 2005. The Vh2 and Vh4 scab resistance genes in two differential hosts derived from Russian apple R12740-7A map to the same linkage group of apple. Mol. Breed. 15: 103-116.

Bus V.G.M., Chagne D., Bassett H.C.M., Bowatte D., Calenge F., Celton M.J., et al., 2007. Genome mapping of three major resistance genes to woolly apple aphid (Eriosoma lanigerum Hausm.). Tree Genet. Genomes 4: 233-236.

Calenge F., Faure A., Goerre M., Gebhardt C., Van De Weg W.E., Parisi L., et al., 2004. Quantitative Trait Loci (QTL) analysis reveals both broad-spectrum and isolate-specific QTL for scab resistance in apple progeny challenged with eight isolates of Venturia inaequalis. Phytopathol. 94(4): 370-379.

Calenge F., Drouet D., Denance C., Van De Weg W.E., Brisset M.N., PAulin J.P., et al., 2005. Identification of a major QTL together with several minor additive or epistatic QTLs for resistance to fire blight in apple in two related progenies. Theor. Appl. Genet. 111: 128-135.

Calenge F., Durel C.E., 2006. Both stable and unstable QTLs for resistance to powdery mildew are detected in apple after four years of field assessments. Mol. Breed. 17: 329-339.

CeviK V., KING G.J., 2002. Resolving the aphid resistance locus $\mathrm{Sd} 1$ on $\mathrm{BAC}$ contig within a sub-telomeric region of Malus linkage group 7. Genome 45: 939-945.

Cevik V., Ryder C.D., Popovich A., Manning K., King G., Seymour G.B., 2010. A fruitfull-like genes is associated with genetic variation for fruit flesh 
firmness in apple (Malus $x$ domestica Borkh.). Tree Genet. Genomes 6: 271-279.

Chagne D., Carlisle C.M., Blond C., Volz K.R., Whitworth C.J., Oraguzie N.C., et al., 2007. Mapping a candidate gene (MdMYB10) for red flesh and foliage colour in apple. BMC Genomics 8(212): $1-12$.

Cheng F.S., Weeden N.F., Brown S.K., Aldwinckle H.S., Gardiner S.E., Bus V.G., 1998. Development of a DNA marker for $\mathrm{Vm}$, a gene conferring resistance to apple scab. Genome 41: 208-214.

Conner P.J., Brown S.K., Weeden N.F., 1997. Randomly amplified polymorphic DNA-based genetic linkage maps of three apple cultivars. J. Am. Soc. Hortic. Sci. 122: 350-359.

Costa F., Stella S., Van De Weg E.W., Guerra W., Cecchinel M., Dallavia J., et al., 2005. Role of the genes Md-ACO1 and Md-ACS1 in ethylene production and shelf life of apple (Malus $x$ domestica Borkh.). Euphytica 141: 181-190.

Costa F., Van De Weg E.W., Stella S., Dondini L., Pratesi D., Musacch S., et al., 2008. Map position and functional allelic diversity of Md-Exp7, a new putative expansin gene associated with fruit softening in apple (Malus $x$ domestica Borkh.) and pear (Pyrus communis). Trees Genet. Genomes 4: 575-586.

Costa F., Peace C.P., Stella S., Serra S., Musacchi S., BAZZANi M., et al., 2010. QTL dynamics for fruit firmness and softening around an ethylene-dependent poligalactouronase gene in apple (Malus $x$ domestica Borkh.). J. Exp. Bot. 61(11): 3029-3039.

Davey M.W., Kenis K., Keulemans J., 2006. Genetic control of fruit Vitamin C contents. Plant Physiol. 142: 343-351.

Dapena E., Minarro M., BlazQuez M.D., 2009. Evaluation on the resistance to the rosy apple aphid using a genetic markers. Acta Hort. 814: 787-790.

Dunemann F., Egerer J., 2010. A major resistance gene from Russian apple 'Antonovka' conferring field immunity against apple scab is closely linked to the Vf locus. Tree Genet. Genomes 6(5): 627-633.

Dunemann F., Peil A., Urbanietz A., Garcia-Libreros T., 2007. Mapping of the apple powdery mildew resistance gene $P L 1$ and its genetic association with an NBS-LRR candidate resistance gene. Plant Breed. 126: 476-481.

Durel C.E., Van De Weg E., Venisse J.S., Parisi L., 2000. Localization of a major gene for apple scab resistance on the European genetic map of the 'Prima' $x$ 'Fiesta' cross. Integrated Control of Pome Fruit Diseases IOBC/WPRS Bull. 23(12): 245-248.

Durel C.E., Parisi L., Laurens F., Van De Weg E., LiebHard R., Koller B., et al., 2003. Genetic dissection of partial resistance against two monoconidial strains of the new race 6 of Venturia inaequalis in apple. Genome 46: 224-234.

Durell C.E., Denance C., Brisset M.N., 2009. Two distinct major QTL for resistance to fire blight co- localize on linkage group 12 in apple genotypes 'Evereste' and Malus floribunda clone 821. Genome 52(2): 139-147.

Evans R.C., Campbell C.S., 2002. The origin of the apple subfamily (Maloideae: Rosaceae) is clarified by DNA sequence data from duplicated GBSSI genes. Am. J. Bot. 89(9): 1478-1484.

Evans K.M., JAMES C.M., 2003. Identification of SCAR markers linked to $P L-w$ mildew resistance in apple. Theor. Appl. Genet. 106: 1178-1183.

Erdin E., Tartarini S., Broggini G.A.L., Gennari F., Sansavini S., Gessler C., et al., 2006. Mapping of apple scab resistance gene $\mathrm{Vb}$. Genome 49: 1238-1245.

Fernandez-Fernandez F., Evans K.M., Clarke J.B., Govan C.L., James C.M., Marić S., et al., 2008. Development of an STS map of an interspecific progeny of Malus. Tree Genet. Genomes 4: 469 -479 .

Gardiner S.E., Murdoch J., Meech S., Rusholme R., Besset H., Cook M., 2003. Candidate resistance genes from an EST database prove a rich source of markers for major genes conferring resistance to important apple pest and diseases. Acta Hort. 622: 141-151.

Gianfranceschi L., Seglias N., Tachini R., Komjanc M., Gessler C., 1998. Simple sequence repeats for the genetic analysis of apple. Theor. Appl. Genet. 96: 1069-1076.

Gessler C., Patocchi A., Sansavini S., Tartarini S., GiANFRANCESCHI L., 2006. Venturia inaequalis resistance in apple. Crit. Rev. Plant Sci. 25: 473-503.

Gygax M., Gianfranceschi L., Liebhard R., Kellerhaus M., Gessler C., Patocchi A., 2004. Molecular markers linked to the apple scab resistance gene $\mathrm{Vbj}$ derived from Malus baccata jackii. Theor. Appl. Genet. 109: 1702-1709.

Han S.E., Seo Y.S., Kim D., Sung S.K., Kim W.T., 2007. Expression of MdCAS1 and MdCAS2, encoding apple $\beta$-cyanoalanine synthase homologs, is concomitantly induced during ripening and implicates MdCASs in the possible role of the cyanide detoxification in Fuji apple (Malus $x$ domestica Borkh.) fruits. Plant Cell Repository 26: 1321-1331.

Han Y., Korban S.S., 2008. An overview of the apple genome through BAC end sequence analysis. Plant Mol. Biol. 67: 581-588.

Han Y., Chagne D., Gasic K., Rikkerink E.H.A., Beever J.E., GARDinER S.E., et al., 2009. BAC-end sequencebased SNPs and bin mapping for rapid integration of physical and genetic maps in apple. Genomics 93: 282-288.

Han Y., Zheng D., VimolmangKang S., Khan M.A., BeEver J.E., Korban S.S., 2011. Integration of physical and genetic maps in apple confirms wholegenome and segmental duplications in the apple genome. J. Exp. Bot. 10: 1-14.

Harada T., Sunako T., Wakasa Y., Soejima J., Satoh T., Nitzeki M., 2000. An allele of the 
1-aminocyclopropane-1-carboxylate synthase gene (Md-CAS1) accounts for the low level of ethylene production in climacteric fruits of some apple cultivars. Theor. Appl. Genet. 101: 742-746.

Hemmat M., Weeden N.F., Manganaris A.G., Lawson D.M., 1994. Molecular marker linkage map for apple. J. Hered. 85: 4-11.

Hemmat M., Brown S.K., Aldwinckle H.S., 2003. Identification and mapping of markers for resistance to apple scab from 'Antonovka' and 'Hansen's baccata \#2'. Acta Hort. 622: 153-161.

Hokanson S.C., Szewc-Mcfadden A.K., Lamboy W.F., MCFERSON J.R., 1998. Microsatellite (SSR) markers reveal genetic identities, genetic diversity and relationships in a Malus $x$ domestica Borkh. core subset collection. Theor. Appl. Genet. 97: 671-683.

Huaracha E., Xu M., Korban S.S., 2004. Narrowing down the region of the $V f$ locus for scab resistance in apple using AFLP-derived SCARs. Theor. Appl. Genet. 108: 274-279.

Hummer K.E., Janick J., 2008. Rosaceae: Taxonomy, Economic Importance, Genomics. In: Genetic and Genomics of Rosaceae. Plant Genetics / Genomics. K.M. Folta and S.E. Gardiner (eds), Springer Science, Business Media: 1-18.

Igarashi M., Abe Y., Hatsuyama Y., Ueda T., FukasawaAkada T., Kon T., et al., 2008. Linkage maps of the apple (Malus $x$ domestica Borkh.) cultivars 'Ralls Janet' and 'Delicious' include newly developed EST markers. Mol. Breed. 22: 95-118.

James C.M., Clarke J.B., Evans K.M., 2004. Identification of molecular markers linked to the mildew resistance gene $P l-d$ in apple. Theor. Appl. Genet. 110: 175-181.

Jha G., Thakur K., Thakur P., 2009 . The Venturia apple pathosystem: Pathogenicity mechanism and plant defense responses. J. Biomed. Biotechnol.: 1-10.

Jung S., Staton M, Lee T., Blenda A., Svancara R., Авbотt A., Main D., 2008. GDR (Genome Database for Rosaceae): integrated web-database for Rosaceae genomics and genetics data. Nucleic Acid Res. 36.

Kenis K., Keulemans J., Davey M.W., 2008. Identification and stability of QTLs for fruit quality traits in apple. Tree Genet. Genomes 4: 647-661.

Kenis K., Keulemans J., 2004. QTL analysis of growth characteristics in apple. Acta Hort. 663: 369-374.

Kenis K., Keulemans J., 2005. Genetic linkage maps of two apple cultivars (Malus $x$ domestica Borkh.) based on AFLP and microsatellite markers. Mol. Breed. 15: 205-219.

Keller-PrzybyŁkowicz S., 2011. Lokalizacja genów związanych jakością owoców na mapie genetycznej odmian jabłoni 'Retina' i 'Topaz'. Ph.D. dissertation, Research Institute of Horticulture, PL.

Khan M.A., Duffy B., Gessler C., Patocchi A., 2006. QTL mapping of fire blight resistance in apple. Mol. Breed. 17: 299-306.
Khan M.A., Durel C.E., Duffy B., Drouet D., Kellerhals M., Gessler C., et al., 2007. Development of molecular markers linked to the 'Fiesta' linkage group 7 major QTL for fire blight resistance and their application for marker-assisted selection. Genome 50: 568-577.

Khan M.A., Han Y., Zhao Y.F., Troggio M., Korban S.S., 2012. A multi-population consensus genetic map reveals inconsistent marker order among maps likely attributed to structural variation in the apple genome. PLoS ONE 7(11): 1-12.

King G.J., Maliepaard C., Lynn J.R., Alston F.H., Durel C.E., Evans K.M., et al., 2000. Quantitative genetic analysis and comparison of physical and sensory descriptors relating to fruit flesh firmness in apple (Malus pumila Mill.). Theor. Appl. Genet. 100: 1074-1084.

Kole C., Аввотт A.G., 2008. Fundamentals of plant genome mapping. Principles and practices of plant genomics. Genome mapping. Science Publishers, USA: 2-67.

Lander E.S., Botstein D., 1989. Mapping Mendelian factors underlying Quantitative Traits using RFLP linkage maps. Genetics 121: 185-199.

Le Roux P.M., Khan M.A., Broggini G.A.L., Duffy B., Gessler C., Patocchi A., 2010. Mapping of quantitative trait loci in the apple cultivars 'Florina' and 'Nova Easygro'. Genome 53(9): 710-712.

Liebhard R., Gessler C., 2000. Possible errors in genome mapping. Integrated Control of Pome Fruit Diseases IOBC/WPRS Bull. 23(12): 127-135.

Liebhard R., Gianfranceschi L., Koller B., Ryder C.D., Tarchini R., Van De Weg E., et al., 2002. Development and characterization of 140 new microsatellites in apple (Malus $x$ domestica Borkh.). Mol. Breed. 10: 217-241.

Liebhard R., Koller B., Gianfranceschi L., Gessler C., 2003a. Creating a saturated reference map for the apple (Malus $x$ domestica Borkh.) genome. Theor. Appl. Genet. 106: 1497-1508.

Liebhard R., Koller B., Patocchi A., Kellerhals M., Pfammatter W., Jertmini M., et al., 2003b. Mapping quantitative field resistance against apple scab in a 'Fiesta' x 'Discovery' progeny. Phytopathol. 93(4): 493-501.

Liebhard R., Kellerhals M., Pfammatter W., Jertmini M., Gessler C., 2003c. Mapping quantitative physiological traits in apple (Malus $x$ domestica Borkh.). Plant Mol. Biol. 52: 511-526.

Ma C.-X., Casella G., Wu R., 2002. Functional Mapping of Quantitative Trait Loci underlying the character process: a theoretical framework. Genetics 161: 1751-1762.

Maliepaard C., Aston F.H., Van Arkel G., Brown L.M., Chevereau E., Dunemann F., et al., 1998. Aligning male and female linkage maps of apple (Malus pumila Mill.) using multi-allelic markers. Theor. Appl. Genet. 97: 60-73. 
N'diaye A., Van De Weg W.E., Kodde L.P., Koller B., Dunemann F., Thirmann M., et al., 2008. Construction of an integrated consensus map of the apple genome based on four mapping populations. Tree Genet. Genome 4: 727-743.

Patocchi A., Vinatzer B.A., Gianfranceschi L., Tartarini S., Zhang H.B., Sansavini S., et al., 1999 a. Construction of a $550 \mathrm{~Kb}$ BAC contig spanning the genomic region containing the apple scab resistance gene Vf. Mol. Gen. Genet. 262: 884-891.

Patocchi A., Gianfranceschi L., Gessler C., 1999 b. Towards the map-based cloning of $V f$ : Fine and physical mapping of the $V f$ region. Theor. Appl. Genet. 99: 1012-1017.

Patocchi A., Walser M., Tartarini S., Broggini G.A.L., Gennari F., Sansavini S., et al., 2005. Identification by chromosome scanning approach (GSA) of a microsatellite tightly associated with the apple scab resistance gene $V m$. Genome 48: 630-636.

Peil A., Garcia-Libreros T., Richter K., Trognitz F.C., Trognitz B., Hanke M.V., et al., 2007 a. Strong evidence for fire blight resistance gene of Malus robusta located on linkage group 3. Plant Breed. 126: 470-475.

Perez-Enciso M., Varona L., 2000. Quantitative trait loci mapping in F2 crosses between outbreed lines. Genetics 155: 391-405.

Roche P., Alston F.H., Maliepaard C., Evans K.M., VRIELINK R., DunEmann F., et. al. 1997. RFLP and RAPD markers linked to the rosy leaf curling aphid resistance gen $(S d 1)$ in apple. Theor. Appl. Genet. 94: 528-533.

SAnzol J., 2010. Dating and functional characterization of duplicated genes in apple (Malus $x$ domestica Borkh.) by analyzing EST data. BMC Plant Biol. 10(87): 1-22.

Soufflet-Freslon V., Gianfranceschi L., Patocchi A., DuREL C.E., 2008. Inheritance studies of apple scab resistance and identification of RVI14, a new major gene that together with other broad-spectrum QTL. Genome 51: 657-667.

Shulaev V., Korban S.S., Sosinski B., Аввot A.G., Aldwinckle H.S., Folta K.M., et al., 2008. Multiple models for Rosaceae Genomics. Plant Physiol. 147: 983-1003.

Silfyerberg-Dilworth E., Matasci C.L., Van De Weg W.E., Van KaAuwen M.P.W., Walser M., Kodde L.P., et al., 2006. Microsatellite markers spanning the apple (Malus $x$ domestica Borkh.) genome. Tree Genet. Genomes 2: 202-224.

Soglio V., Costa F., Molthoff J.W., Mieke W., WeemenHendriks J., Schouten H.J., et al., 2009. Transcription analysis of apple fruit development using cDNA microarrays. Tree Genet. Genomes 5(4): 685-698.

Soriano J.M., Joshi S.G., Van KaAuwen W., Noordijk Y., Groenwold R., Henken B., et al., 2009. Identification and mapping of the novel apple scab resistance gene Vd3. Tree Genet. Genomes 5: 475-482.
Schouten H.J., Van De Weg W.E., Carling J., Khan A.S., Mckay S.J., Van KaAuwen M.P.W., et al., 2012. Diversity arrays technology (DArT) markers in apple for genetic linkage maps. Mol. Breed. 29: 645-660.

Tartarini S., Gianfranceschi L., Sansavini S., Gessler C., 1999. Development of reliable PCR markers for the selection of the $V f$ gene conferring scab resistance in apple. Plant Breed. 118: 183-186.

TARTARInI S., 2003. Marker-Assisted Selection in Pome fruit breeding. MAS: A fast track to increase genetic gain in plant and animal breeding; Session I: MAS in plants: 23-28.

Tartarini S., Gennari F., Pratesi D., Palazzetti C., SAnsavini S., PArisi L., et al., 2004. Characterization and genetic mapping of a major scab resistance gene from the old Italian apple cultivar 'Durello di Forli'. Acta Hort. 663: 129-133.

VAN OOIJEN J.W., 1999. LOD significance thresholds for QTL analysis in experimental populations of diploid species. Heredity 83: 613-624.

Van Ooijen J.W., Voorrips R.E., 2001. JoinMap 3.0, Software for the calculation of genetic linkage maps. Plant Research International, Wageningen, The Netherlands.

Velasco R., Zharkikh A., Affourtit J., Dhingra A., Cestaro A., Kalyanaraman A., et al., 2010. The genome of the domesticated apple (Malus $x$ domestica Borkh.). Nature Genet. 42(10): 833-841.

Xu S., Atchley W., 1995. A random model approach to interval mapping of Quantitative Trait Loci. Genetics 141: 1189-1197.

\section{HISTORIA MAPOWANIA GENOMU JABŁONI}

Streszczenie: Prace nad uzyskiwaniem genetycznych oraz fizycznych map genomu jabłoni $(M . \times$ domestica), rozpoczętew końcuXX wieku,znacząco poszerzyły wiedzę dotyczącą ewolucji i struktury genomu tego gatunku. Mapy nowej generacji, zawierające pełną sekwencję nukleotydową stały się cennym narzędziem podczas tworzenia programów krzyżowań ukierunkowanych na introgresję genów kodujących lub modulujących ważne gospodarczo cechy i gromadzenie wielu $\mathrm{z}$ nich $\mathrm{w}$ genomach nowych odmian. Istniejące mapy genomów odmian jabłoni umożliwiają nie tylko rozpoznanie mechanizmów współdziałania genów, ale również identyfikację pożądanych alleli w populacjach potomnych. Baza danych, wygenerowana podczas sporządzania map stanowi 'kamień milowy' dla rozwoju hodowli jabłoni. Niemniej przed skorzystaniem z tych danych winny być one poddane dogłębnej weryfikacji. 